\title{
FUZZY LOGIC APPROACH FOR HEART RATE VARIABILITY
}

\author{
Martynenko A., Raimondi G., Barsi L., Budreiko N., Maliarova L.
}

Intrioution. The heart rate variability (HRV) is based on measuring (time) intervals between R-peaks (of RR-intervals) of an electrocardiogram (ECG) and plotting a rhythmogram on their basis with its subsequent analysis by various mathematical methods that are classified as Time Domain (TD), Frequency Domain (FD) and Nonlinear (NM) [1,2]. Diversity of methods and approaches to analysis of HRV is stemming from complexity and nonlinearity of the phenomenon itself, as well as from greater diversity of physiological reactions of an organism, both in normal and pathological states. Therefore, it appears relevant and important to incorporate currently existing HRV indicators and norms into a unified Fuzzy Logic (FL) methodology, which in turn will allow to integrally assess each metric and HRV results as a whole.

Objective. We propose a Fuzzy Logic algorithm for incorporating into a single view of each metric, Time Domain, Frequency Domain, Nonlinear Methods and HRV as a whole.

Materials and methods. We define by FL the extent of belonging to normal state both for each distinct HRV metric - TD, FD and NM, and for a patient's HRV in general. Membership functions of any HRV index and defuzzification rules for FL scores was defined. In order to implement the proposed algorithm, specified parameters of mean values of HRV (M) indicators and their standard deviation $(\sigma)$ have been found in scientific publications on HRV [1, 3, 7, 8, 9, 10]. We use for FL algorithm demonstration a long-term HRV records by Massachusetts Institute of Technology - Boston's Beth Israel Hospital (MIT-BIH) from [11], a free-access, on-line archive of physiological signals for Normal Sinus Rhythm (NSR) RR Interval, Congestive Heart Failure (CHF) RR Interval and Atrial Fibrillation (AF) Databases [12].

Conclusion. In this article, we have presented a comprehensive view of HRV by Fuzzy Logic technology and thoroughly examined the peculiarities of its application and interpretation. Of all considered examples of FL analysis, the worst result is demonstrated by a patient from the AF group, while the best one belongs to a patient from the NSR group. Difference in FL Scores between these patients from NSR and CHF groups is almost 4 times, while between patients from NSR and AF groups it is almost 6 times. It appears especially important to implement such a design in portable medical devices for quick and easy interpretation of numerous parameters measured by them.

KEY WORDS: heart rate variability, fuzzy logic

\section{INFORMATION ABOUT AUTHORS}

Martynenko Alexander, D. Sc., Professor, Department of Hygiene and Social Medicine, V. N. Karazin Kharkiv National University, 6, Svobody sq., Kharkiv, Ukraine, 61022; e-mail: Alexander.v.martynenko@karazin.ua, ORCID ID: https://orcid.org/0000-0002-0609-2220

Gianfranco Raimondi, MD, PhD, Prof., Sapienza University of Rome (Italy), 5, Piazzale Aldo Moro, Rome, Italy, 00185; e-mail: gianfrancoraimondi@uniroma1.it

L. Barsi, PhD, Sapienza University of Rome (Italy), 5, Piazzale Aldo Moro Rome, Italy, 00185.

Budreiko Nikita, Assistant, Department of hygiene and social medicine, V. N. Karazin Kharkiv National University School of Medicine, 6, Svobody sq., Kharkiv, Ukraine, 61022, e-mail: nbudreiko@ protonmail.com

Maliarova Liudmila, Assistant, Department of hygiene and social medicine, V. N. Karazin Kharkiv National University School of Medicine, 6, Svobody sq., Kharkiv, Ukraine, 61022, e-mail: 1.v.maliarova@karazin.ua

\section{INTRODUCTION}

The heart rate variability (HRV) is based on measuring (time) intervals between R-peaks (of RR-intervals) of an electrocardiogram (ECG) and plotting a rhythmogram on their basis with its subsequent analysis by various mathematical methods that are classified as Time Domain (TD), Frequency Domain (FD) and Nonlinear
(NM) [1,2]. Diversity of methods and approaches to analysis of HRV is stemming from complexity and nonlinearity of the phenomenon itself, as well as from greater diversity of physiological reactions of an organism, both in normal and pathological states. Initially mentioned in [1] are 11 indicators of TD, 7 indicators of FD, 6 indicators of NM and 5 ways of graphical 
analysis of NM. However, during the 25 years of HRV development and improvement since [1] had been published, the number of HRV indicators has increased significantly. This is especially true for the area of NM, where the number of distinct variants of $\mathrm{NM}$ indicators has increased multi-fold. Thus, for example, in [3] there are 42 various HRV indicators discussed for the area of NM. A good review of HRV metrics and norms is provided in [4], in which it is highlighted that every one of the reviewed HRV metrics - TD, FD and NM, has its own distinct features and advantages. Therefore, it appears relevant and important to incorporate currently existing HRV indicators and norms into a unified methodology, which in turn will allow to integrally assess each metric and HRV results as a whole.

\section{MATERIALS AND METHODS}

Soft computing is a relatively new approach to solving complex problems, whenever traditional methods and algorithms prove ineffective due to extensiveness and diversity of systems in question. It includes various algorithmic methods, primary of which is fuzzy logic [5]. Fuzzy Logic (FL) has become widespread in medical diagnostics as one of the key elements of computer-aided diagnosis [6]. One of the advantages of FL is the ability to incorporate various not always accurately defined data, received from observing a system, into a unified mathematical model of a fuzzy logical argument about state of the system. In our case, we define the extent of belonging to normal state both for each distinct HRV metric - TD, FD and NM, and for a patient's HRV in general. Membership functions of any HRV index are presented on Fig. 1.

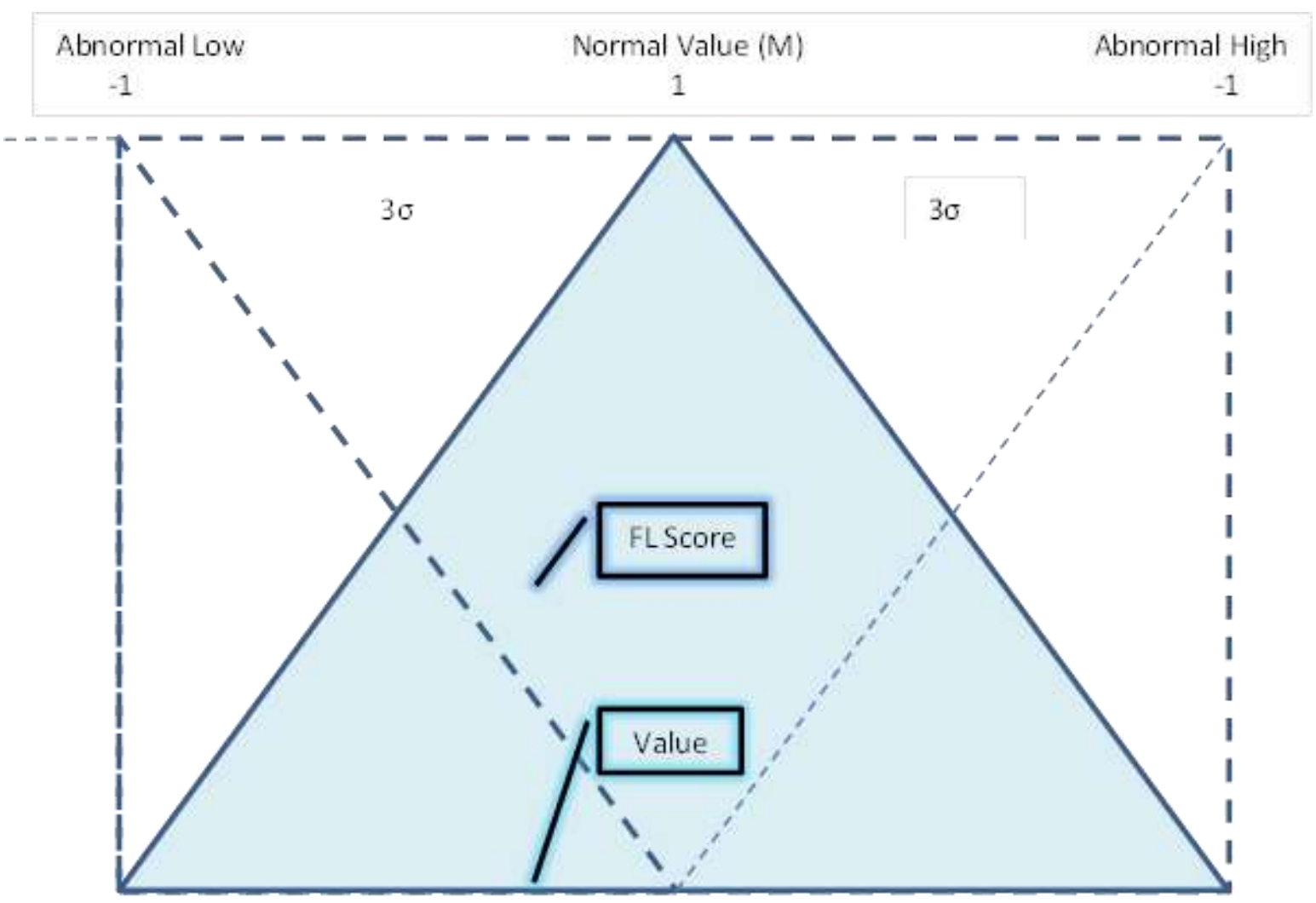

Fig. 1. Membership functions of HRV indices

We compare the notion of 'Norm' with a mean value of HRV, established on standard records of RR-intervals. Notions of 'Abnormal Low' or 'Abnormal High' are compared with values of indices, which are away from a mean $\mathrm{M}$ value by a parameter of $3 \sigma$. Statistically, it corresponds to $99.8 \%$ of confidence level of validity of statement about abnormal value of a parameter. Thus, let's construct the defuzzification rules for FL scores:

$$
\text { FL Score }=\left\{\begin{array}{c}
-1 \forall \text { Value }<M-3 \sigma \\
\frac{4 \operatorname{sign}(\text { Value }-M)(M-\text { Value })}{3 \sigma}+1 \\
-1 \forall \text { Value }>M+3 \sigma
\end{array}\right.
$$


According to presented defuzzification rules, we calculate FL scores of all HRV indicators. Mean values of FL scores for each metric and for all HRV indicators will define the extent of validity of argument about normalcy of state of each metric and of the whole HRV.

In order to implement the proposed algorithm, specified parameters of mean values of HRV (M) indicators and their standard deviation $(\sigma)$ will be required.
Specified parameters have been found in scientific publications on HRV and presented in following groups: Mean Normal Values (disregarding additional factors), Age (taking Age into account), Gender (taking Gender and Age into account), Circadian (taking Time of Day and Age into account). All collected data are represented mostly by standard 5-minute HRV records (or 5-minute fragments of more lengthy records), with reference to a source of these data provided.

Mean Normal Values (disregarding additional factors)

Normal Values of Standard Measures of HRV, Mean \pm SD

\begin{tabular}{|c|c|c|}
\hline \multicolumn{3}{|c|}{ Time Domain Analysis of Nominal 24 hours $[1,7]$} \\
\hline Variable & Units & Normal Values (mean \pm SD) \\
\hline SDNN [1] & $\mathrm{ms}$ & $141 \pm 39$ \\
\hline SDANN [1] & $\mathrm{ms}$ & $127 \pm 35$ \\
\hline RMSSD [1] & $\mathrm{ms}$ & $27 \pm 12$ \\
\hline HRV triangular index [1] & & $37 \pm 15$ \\
\hline Recurrence [7] & $\%$ & $4.79 \pm 2.33$ \\
\hline \multicolumn{3}{|c|}{ Time Domain Analysis of Short-Term Recording [8] } \\
\hline Variable & Units & Normal Values (mean \pm SD) \\
\hline $\mathrm{mRR}$ & $\mathrm{ms}$ & $926 \pm 90$ \\
\hline SDNN & $\mathrm{ms}$ & $50 \pm 16$ \\
\hline RMSSD & $\mathrm{ms}$ & $42 \pm 15$ \\
\hline \multicolumn{3}{|c|}{ Spectral Analysis of Stationary Supine 5-min Recording $[1,8]$} \\
\hline Variable & Units & Normal Values (mean \pm SD) \\
\hline Total Power (TP) [1] & $\mathrm{ms}^{2}$ & $3466 \pm 1018$ \\
\hline Low Frequency (LF) [1] & $\mathrm{ms}^{2}$ & $1170 \pm 416$ \\
\hline High Frequency (HF) [1] & $\mathrm{ms}^{2}$ & $975 \pm 203$ \\
\hline LF [1] & $\mathrm{nu}$ & $54 \pm 4$ \\
\hline HF [1] & nu & $29 \pm 3$ \\
\hline LF/HF [1] & & $1.5-2.0^{*}$ \\
\hline LF/HF [8] & & $2.8 \pm 2.6$ \\
\hline \multicolumn{3}{|c|}{ Nonlinear Methods, 5-min Subsets of 24 hours RR Records [7] } \\
\hline Variable & Units & Normal Values (mean \pm SD) \\
\hline Entropy (EnRE) & & $1.72 \pm 0.47$ \\
\hline Correlation Dimension (D2) & & $2.10 \pm 0.28$ \\
\hline Time Irreversibility $(\mathrm{z}>1.96)$ & & $3.19 \pm 1.78$ \\
\hline
\end{tabular}

* Useless for current FL algorithm without SD

Age (taking Age into account)

Table 2

Aging Effects on 24-h Heart Rate Variability and Heart Rate by Decade [9], Mean \pm SD

\begin{tabular}{|c|c|c|c|c|c|c|}
\hline $\begin{array}{c}\text { Age } \\
(\mathrm{yr})\end{array}$ & $\begin{array}{c}\text { SDNN } \\
(\mathrm{ms})\end{array}$ & $\begin{array}{c}\text { SDANN } \\
(\mathrm{ms})\end{array}$ & $\begin{array}{c}\text { SDNN Index } \\
(\mathrm{ms})\end{array}$ & $\begin{array}{c}\text { rMSSD } \\
(\mathrm{ms})\end{array}$ & $\begin{array}{c}\text { pNN50 } \\
(\%)\end{array}$ & $\begin{array}{c}\text { HR } \\
(\mathrm{beats} / \mathrm{min})\end{array}$ \\
\hline $10-19$ & $176 \pm 38$ & $159 \pm 35$ & $81 \pm 20$ & $53 \pm 17$ & $25 \pm 13$ & $80 \pm 10$ \\
\hline $20-29$ & $153 \pm 44$ & $137 \pm 43$ & $72 \pm 22$ & $43 \pm 19$ & $18 \pm 13$ & $79 \pm 10$ \\
\hline $30-39$ & $143 \pm 32$ & $130 \pm 33$ & $64 \pm 15$ & $35 \pm 11$ & $13 \pm 9$ & $78 \pm 7$ \\
\hline $40-49$ & $132 \pm 30$ & $116 \pm 31$ & $60 \pm 13$ & $31 \pm 11$ & $10 \pm 9$ & $78 \pm 7$ \\
\hline $50-59$ & $121 \pm 27$ & $106 \pm 27$ & $52 \pm 15$ & $25 \pm 9$ & $6 \pm 6$ & $76 \pm 9$ \\
\hline $60-69$ & $121 \pm 32$ & $111 \pm 31$ & $42 \pm 13$ & $22 \pm 6$ & $4 \pm 5$ & $77 \pm 9$ \\
\hline $70-79$ & $124 \pm 22$ & $114 \pm 20$ & $43 \pm 11$ & $24 \pm 7$ & $4 \pm 5$ & $72 \pm 9$ \\
\hline $80-99$ & $106 \pm 23$ & $95 \pm 24$ & $37 \pm 12$ & $21 \pm 6$ & $3 \pm 3$ & $73 \pm 10$ \\
\hline
\end{tabular}


Gender (taking Gender and Age into account)

General age and gender dependency of $\mathrm{HRV}$ indices for two age clustered (25-49 years and 50-74 years) female and/or male subject groups [3], Mean \pm SD

\begin{tabular}{|c|c|c|c|c|c|}
\hline \multirow{3}{*}{$\begin{array}{c}\text { HRV } \\
\text { methods }\end{array}$} & \multirow{2}{*}{$\begin{array}{c}\text { HRV } \\
\text { indices }\end{array}$} & $\begin{array}{c}\text { Females, } \\
25-49 \text { y.o. }\end{array}$ & $\begin{array}{c}\text { Males, } \\
25-49 \text { y.o. }\end{array}$ & $\begin{array}{c}\text { Females, } \\
50-74 \text { y.o. }\end{array}$ & $\begin{array}{c}\text { Males, } \\
50-74 \text { y.o. }\end{array}$ \\
\cline { 2 - 6 } & RR, ms & $901 \pm 117$ & $930 \pm 133$ & $880 \pm 115$ & $911 \pm 128$ \\
\hline \multirow{4}{*}{$\begin{array}{c}\text { Time } \\
\text { Domain }\end{array}$} & SDNN, ms & $44.9 \pm 19.2$ & $45.8 \pm 18.8$ & $31.6 \pm 13.6$ & $33.0 \pm 14.8$ \\
\cline { 2 - 6 } & rMSSD, ms & $36.5 \pm 20.1$ & $34.0 \pm 18.3$ & $22.0 \pm 13.2$ & $20.5 \pm 11.0$ \\
\cline { 2 - 6 } & pNN50, ms & $0.17 \pm 0.18$ & $0.15 \pm 0.16$ & $0.05 \pm 0.09$ & $0.04 \pm 0.07$ \\
\hline \multirow{4}{*}{$\begin{array}{c}\text { Frequency } \\
\text { Domain }\end{array}$} & LF/HF & $2.09 \pm 2.05$ & $3.33 \pm 3.47$ & $2.75 \pm 2.93$ & $4.29 \pm 4.06$ \\
\cline { 2 - 6 } & LF/TP & $0.31 \pm 0.14$ & $0.38 \pm 0.16$ & $0.28 \pm 0.13$ & $0.31 \pm 0.15$ \\
\cline { 2 - 6 } & HF/TP & $0.24 \pm 0.15$ & $0.19 \pm 0.13$ & $0.17 \pm 0.12$ & $0.12 \pm 0.10$ \\
\cline { 2 - 6 } & LFn, \% & $0.58 \pm 0.19$ & $0.67 \pm 0.17$ & $0.63 \pm 0.18$ & $0.72 \pm 0.17$ \\
\hline \multirow{5}{*}{$\begin{array}{c}\text { NFn, \% } \\
\text { Methodinear }\end{array}$} & Shannon En & $3.08 \pm 0.49$ & $2.99 \pm 0.47$ & $2.50 \pm 0.52$ & $2.44 \pm 0.49$ \\
\cline { 2 - 6 } & SD1 & $25.8 \pm 14.2$ & $24.1 \pm 13.0$ & $15.5 \pm 9.3$ & $14.5 \pm 7.8$ \\
\cline { 2 - 6 } & SD2 & $57.5 \pm 24.4$ & $59.7 \pm 24.2$ & $41.3 \pm 17.6$ & $43.9 \pm 20.1$ \\
\cline { 2 - 6 } & SD1/SD2 & $0.45 \pm 0.16$ & $0.40 \pm 0.13$ & $0.38 \pm 0.15$ & $0.34 \pm 0.14$ \\
\cline { 2 - 6 } & DFA, $\alpha 1$ & $0.92 \pm 0.23$ & $0.98 \pm 0.22$ & $1.06 \pm 0.24$ & $1.13 \pm 0.23$ \\
\cline { 2 - 6 } & DFA, $\alpha 2$ & $0.91 \pm 0.20$ & $0.87 \pm 0.22$ & $0.98 \pm 0.17$ & $0.97 \pm 0.20$ \\
\hline
\end{tabular}

Circadian (taking Time of Day and Age into account)

Table 4

Normal Values of Standard Measures of HRV [10], Mean \pm SE

\begin{tabular}{|c|c|c|c|c|c|c|}
\hline \multirow{2}{*}{$\begin{array}{l}\text { Age, years } \\
\text { Times of Day }\end{array}$} & \multicolumn{2}{|c|}{$20-39$} & \multicolumn{2}{|c|}{$40-59$} & \multicolumn{2}{|c|}{$60-80$} \\
\hline & day & night & day & night & day & night \\
\hline \multicolumn{7}{|c|}{ Time Domain } \\
\hline $\mathrm{mRR}, \mathrm{ms}$ & $754 \pm 35$ & $883 \pm 33$ & $832 \pm 19$ & $963 \pm 20$ & $832 \pm 15$ & $937 \pm 22$ \\
\hline SDNN-i, ms & $59.8 \pm 3.7$ & $67.8 \pm 3.5$ & $51.6 \pm 1.7$ & $56.5 \pm 1.8$ & $45.0 \pm 1.7$ & $49.7 \pm 2.3$ \\
\hline SDANN, ms & $84 \pm 6.0$ & $133 \pm 9.6$ & $77.5 \pm 3.8$ & $88.6 \pm 5.1$ & $76.6 \pm 2.9$ & $90.1 \pm 5.3$ \\
\hline RMSSD, ms & $32.2 \pm 2.9$ & $42.3 \pm 3.3$ & $27.7 \pm 1.2$ & $32.5 \pm 2.2$ & $26.0 \pm 1.7$ & $29.5 \pm 1.7$ \\
\hline pNN50, \% & $9.8 \pm 2.4$ & $17.5 \pm 2.6$ & $6.3 \pm 0.8$ & $10.2 \pm 2.2$ & $4.8 \pm 0.9$ & $7.1 \pm 1.1$ \\
\hline \multicolumn{7}{|c|}{ Frequency Domain } \\
\hline $\mathrm{VLF}, \mathrm{ms}^{2}$ & $1677 \pm 136$ & $2587 \pm 251$ & $1542 \pm 145$ & $1994 \pm 133$ & $1146 \pm 89$ & $1505 \pm 124$ \\
\hline $\mathrm{LF}, \mathrm{ms}^{2}$ & $810 \pm 92$ & $1347 \pm 110$ & $710 \pm 63$ & $922 \pm 100$ & $454 \pm 64$ & $661 \pm 73$ \\
\hline $\mathrm{HF}, \mathrm{ms}^{2}$ & $540 \pm 98$ & $1113 \pm 125$ & $386 \pm 25$ & $528 \pm 53$ & $258 \pm 26$ & $344 \pm 34$ \\
\hline $\mathrm{LF} / \mathrm{HF}$ & $1.50 \pm 0.39$ & $1.21 \pm 0.19$ & $1.83 \pm 0.20$ & $1.74 \pm 0.2$ & $1.85 \pm 0.17$ & $1.94 \pm 0.14$ \\
\hline LFn, $\%$ & $59.8 \pm 2.2$ & $54.6 \pm 1.9$ & $64.8 \pm 1.8$ & $63.5 \pm 2.5$ & $62.8 \pm 2.0$ & $64.5 \pm 1.8$ \\
\hline HFn, \% & $40.1 \pm 2.2$ & $45.3 \pm 1.9$ & $35.1 \pm 1.7$ & $36.4 \pm 2.5$ & $37.1 \pm 2.0$ & $35.4 \pm 1.8$ \\
\hline
\end{tabular}

In order to demonstrate the proposed algorithm in action, we used long-term HRV records by Massachusetts Institute of Technology - Boston's Beth Israel Hospital (MIT-BIH) from [11]

(http://www.physionet.org), a free-access, online archive of physiological signals. Normal Sinus Rhythm (NSR) RR Interval Database includes beat annotation files for 54 longterm ECG recordings of subjects in normal sinus rhythm (30 men, aged 28.5 to 76 , and
24 women, aged 58 to 73). Congestive Heart Failure (CHF) RR Interval Database includes beat annotation files for 29 long-term ECG recordings of subjects aged 34 to 79 , with congestive heart failure (NYHA classes I, II, and III). Subjects include $8 \mathrm{men}$ and 2 women; gender of the remaining 21 subjects is not known. The original electrocardiography (ECG) signals for both NSR and CHF RR interval databases were digitized at $128 \mathrm{~Hz}$, and the beat annotations 
were obtained by automated analysis with manual review and correction. The MIT-BIH Atrial Fibrillation (AF) Database [12] includes 25 long-term ECG recordings of human subjects with atrial fibrillation (mostly paroxysmal). The individual recordings are each 10 hours in duration, and contain two ECG signals each sampled at 250 samples per second with 12-bit resolution over a range of \pm 10 millivolts. The original analog recordings were made at Boston's Beth Israel Hospital (now the Beth Israel Deaconess Medical Center) using ambulatory ECG recorders with a typical recording bandwidth of approximately $0.1 \mathrm{~Hz}$ to $40 \mathrm{~Hz}$.

\section{RESULTS AND DISCUSSION}

Demonstration of performance of the proposed algorithm and interpretation of FL results will be done on randomly selected HRV records of MIT-BIH Database for NSR, $\mathrm{CHF}$ and AF groups. Numbers of analyzed records, information about field and age of patients (if such information was available), as well as results of FL analysis are presented in Table 5. As a norm, for the purposes of FL analysis we have used data from various tables 1-4 to provide completeness of study for each metric - TD, FD and NM.

FL analysis for TD, FD, NM and total HRV (NSR, CHF and AF patients)

Table 5

\begin{tabular}{|c|c|c|c|c|c|c|c|c|}
\hline \multirow[t]{2}{*}{ HRV index } & \multicolumn{2}{|c|}{$\begin{array}{l}\text { NSR (nsr002) } \\
\text { Male, } 67 \text { y.o. }\end{array}$} & \multicolumn{2}{|c|}{$\begin{array}{l}\text { CHF (chf204) } \\
\text { Male, } 62 \text { y.o, } \\
\text { NYHA class III }\end{array}$} & \multicolumn{2}{|c|}{$\begin{array}{l}\text { AF }(03665) \\
\text { before AF episode }\end{array}$} & \multicolumn{2}{|c|}{$\begin{array}{l}\text { AF }(03665) \\
\text { AF episode }\end{array}$} \\
\hline & Value & FL score & Value & FL score & Value & FL score & Value & FL score \\
\hline \multicolumn{9}{|c|}{ Time Domain (TD) } \\
\hline $\mathrm{mRR}, \mathrm{ms}$ & 915 & 0.958 & 741 & -0.771 & 1137 & -1.000 & 1157 & -1.000 \\
\hline SDNN, ms & 51 & -0.622 & 25 & 0.279 & 162 & -1.000 & 224 & -1.000 \\
\hline $\mathrm{rMSSD}, \mathrm{ms}$ & 25 & 0.455 & 17 & 0.576 & 278 & -1.000 & 326 & -1.000 \\
\hline pNN50, \% & 4.8 & 1.000 & 0.9 & -1.000 & 15 & -1.000 & 87 & -1.000 \\
\hline HRV TI & 13.7 & -1.000 & 5.5 & -1.000 & 31 & 0.467 & 5.7 & -1.000 \\
\hline Recurrence, $\%$ & 13 & -1.000 & 30 & -1.000 & 23 & -1.000 & 8 & -0.837 \\
\hline $\begin{array}{l}\text { Mean of FL score for } \\
\text { TD (subtotal) }\end{array}$ & & $\begin{array}{l}-0.035 \\
(-0.209) \\
\end{array}$ & & $\begin{array}{l}-0.486 \\
(-2.916) \\
\end{array}$ & & $\begin{array}{l}-0.756 \\
(-4.533) \\
\end{array}$ & & $\begin{array}{l}-0.973 \\
(-5.837) \\
\end{array}$ \\
\hline \multicolumn{9}{|c|}{ Frequency Domain $(F D)$} \\
\hline TP. ms & 3332 & 0.824 & 984 & -1.000 & 756 & -1.000 & 4266 & -0.048 \\
\hline LFn, $\%$ & 57 & -1.000 & 55 & -1.000 & 9 & -1.000 & 27 & -1.000 \\
\hline HFn, $\%$ & 43 & -1.000 & 45 & -1.000 & 91 & -1.000 & 73 & -1.000 \\
\hline $\mathrm{LF} / \mathrm{HF}$ & 1.35 & 0.034 & 1.23 & -0.005 & 0.1 & -0.376 & 0.37 & -0.287 \\
\hline $\mathrm{LF} / \mathrm{TP}$ & 0.06 & -1.000 & 0.03 & -1.000 & 0.02 & -1.000 & 0.26 & 0.556 \\
\hline HF/TP & 0.04 & -0.067 & 0.02 & -0.333 & 0.19 & 0.067 & 0.70 & -1.000 \\
\hline $\begin{array}{l}\text { Mean FL score for } \\
\text { FD (subtotal) }\end{array}$ & & $\begin{array}{l}-0.368 \\
(-2.209)\end{array}$ & & $\begin{array}{l}-0.723 \\
(-4.338)\end{array}$ & & $\begin{array}{l}-0.718 \\
(-4.309)\end{array}$ & & $\begin{array}{l}-0.463 \\
(-2.779)\end{array}$ \\
\hline \multicolumn{9}{|c|}{ Nonlinear Methods (NM) } \\
\hline Entropy, EnRE & 1.70 & 0.943 & 0.99 & -1.000 & 0.96 & -1.000 & 1.30 & -0.191 \\
\hline $\begin{array}{l}\text { Correlation dimension, } \\
\text { D2 }\end{array}$ & 1.99 & 0.476 & 1.78 & -0.524 & 2.47 & -1.000 & 8.98 & -1.000 \\
\hline Irreversibility, z & 2.18 & 0.243 & 2.80 & 0.708 & 3.93 & 0.446 & 1.78 & -0.056 \\
\hline $\begin{array}{l}\text { Poincare Plot, } \\
\text { SD1/SD2 }\end{array}$ & 0.12 & -1.000 & 0.15 & -0.081 & 1.59 & -1.000 & 1.05 & -1.000 \\
\hline DFA, $\alpha 1$ & 1.43 & -0.739 & 1.00 & 0.246 & 0.20 & -1.000 & 0.57 & -1.000 \\
\hline DFA, $\alpha 2$ & 1.07 & 0.333 & 1.83 & -1.000 & 0.17 & -1.000 & 0.57 & -1.000 \\
\hline $\begin{array}{l}\text { Mean of FL score for } \\
\text { NM (subtotal) }\end{array}$ & & $\begin{array}{l}0.043 \\
(0.256)\end{array}$ & & $\begin{array}{l}-0.275 \\
(-1.651)\end{array}$ & & $\begin{array}{l}-0.759 \\
(-4.554)\end{array}$ & & $\begin{array}{l}-0.708 \\
(-4.247)\end{array}$ \\
\hline $\begin{array}{l}\text { Mean of FL score } \\
\text { (Total) }\end{array}$ & & $\begin{array}{l}-0.12 \\
(-2.16)\end{array}$ & & $\begin{array}{l}-0.50 \\
(-8.91)\end{array}$ & & $\begin{array}{l}-0.74 \\
(-13.39)\end{array}$ & & $\begin{array}{l}-0.72 \\
(-12.86)\end{array}$ \\
\hline $\begin{array}{l}\text { Total state of HRV } \\
\text { (defuzzification) }\end{array}$ & \multicolumn{2}{|c|}{$\begin{array}{l}\text { Premorbid } 88 \% \\
\text { Abnormal } 12 \%\end{array}$} & \multicolumn{2}{|c|}{$\begin{array}{l}\text { Abnormal } 50 \% \\
\text { Premorbid } 50 \%\end{array}$} & \multicolumn{2}{|c|}{$\begin{array}{l}\text { Abnormal } 74 \% \\
\text { Premorbid } 26 \%\end{array}$} & \multicolumn{2}{|c|}{$\begin{array}{l}\text { Abnormal } 72 \% \\
\text { Premorbid } 28 \%\end{array}$} \\
\hline
\end{tabular}


Let us analyze the results shown in Table 5, in greater detail:

Normal Sinus Rhythm (NSR). Premorbid state of HRV is $88 \%$ and $12 \%$ total abnormality are 'true'. The best metric is NM: $96 \%$ of premorbid state of HRV and $4 \%$ of normal state are 'true'. The worst metric is FD: $63 \%$ of premorbid state of HRV and $37 \%$ of abnormality are 'true'.

Congestive Heart Failure (CHF). $50 \%$ total abnormality is 'true'. The best metric is NM: $72 \%$ of premorbid state of HRV and $28 \%$ of abnormality are 'true'. The worst metric is FD: $72 \%$ of abnormality is 'true'.

Atrial Fibrillation (AF). $74 \%$ total abnormality is 'true' for before/after AF episodes. During AF episode $72 \%$ total abnormality is 'true'. Therefore, despite significant discrepancy of some HRV indicators, total difference in FL Scores before $\mathrm{AF}$ episodes and during an $\mathrm{AF}$ episode is just about $2 \%$, since it is one and the same patient and the indicators have been measured in a small time range $(<<24 \mathrm{~h}$.). The best metric is FD for both cases and during AF is better than before/after AF. The worst metric is $\mathrm{TD}$ during $\mathrm{AF}$ and $\mathrm{NM}$ for before/after $\mathrm{AF}$ episodes.

Combined view for all HRV metrics showed on the Fig. 2. All patients from Tabl. 5 presented together with point for $100 \%$ of 'true' Premorbid state (TD - 0, FD $0, \mathrm{NM}-0$ ).

Of all considered examples of FL analysis, the worst result is demonstrated by a patient from the AF group, while the best one belongs to a patient from the NSR group. Difference in FL Scores between these patients from NSR and CHF groups is almost 4 times, while between patients from NSR and $\mathrm{AF}$ groups it is almost 6 times.

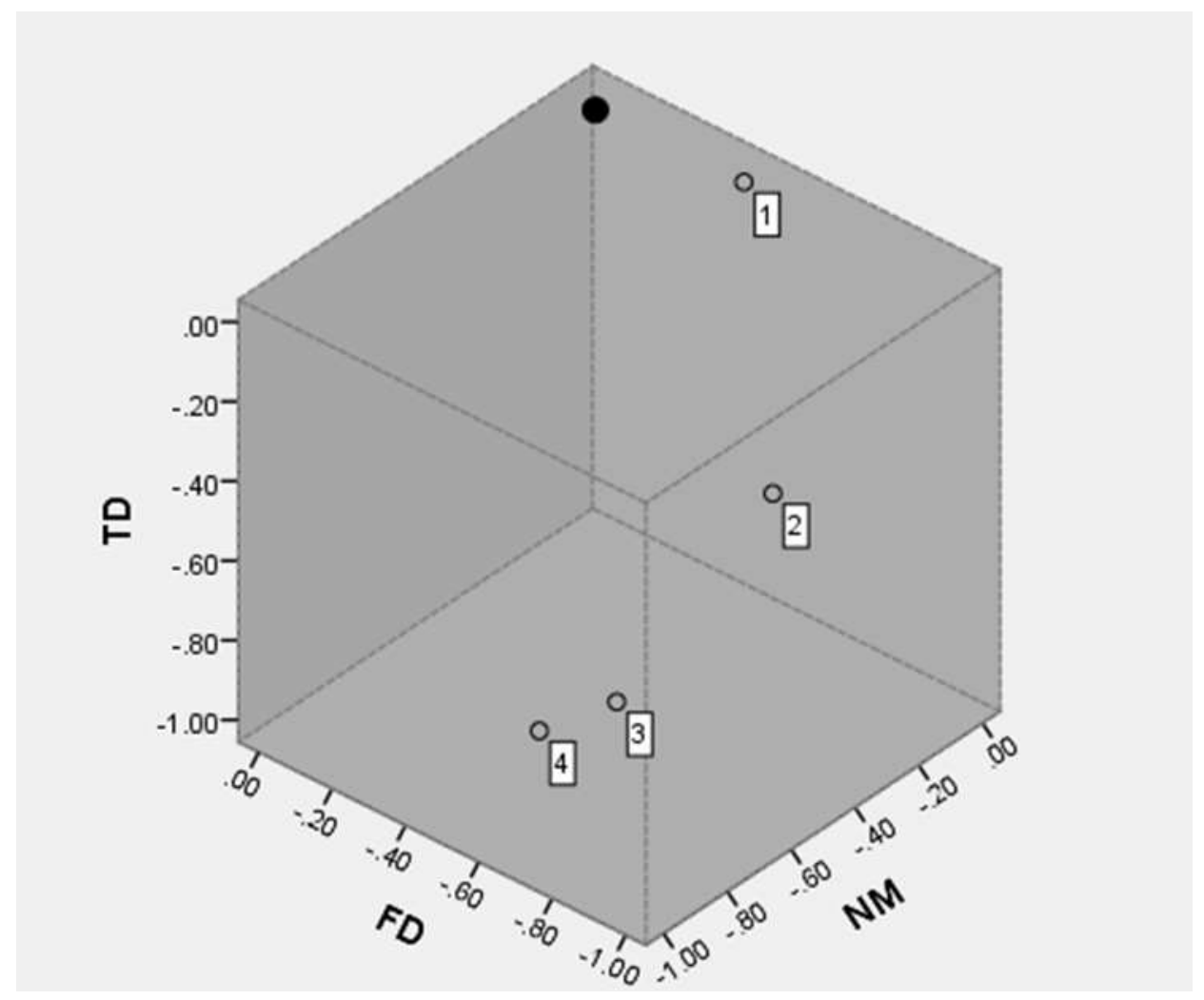

Fig. 2. Combined view for HRV metrics (patients from Tabl. 5: 1 - NSR; 2 - CHF; 3 - AF 'before episode'; 4 - AF 'during episode').

\section{CONCLUSIONS}

HRV is a complex phenomenon, study of which requires various approaches and methods. HRV metrics are characterized concisely and clearly in [4]: 'Time-domain indices of HRV quantify the amount of variability in measurements of the interbeat interval (IBI), which is the time period between successive heartbeats... Frequencydomain measurements estimate the distribution of absolute or relative power into four frequency bands... Non-linear indices measure the unpredictability and complexity 
of a series of IBIs'. However, a comprehensive view of HRV is only possible when there is a technology similar to Fuzzy Logic, one that allows to combine all used methods and approaches into an integral assessment. In this article, we have presented a technology similar to Fuzzy Logic and thoroughly examined the peculiarities of its application and interpretation. It appears especially important to implement such a design in portable medical devices for quick and easy interpretation of numerous parameters measured by them.

\section{REFERENCES}

1. Task force of the European society of cardiology and the North American society of pacing and electrophysiology. Heart rate variability - standards of measurement, physiological interpretation, and clinical use. (1996). Circulation, 1996. vol. 93, iss. 5, pp.1043-1065.

2. Yabluchansky N., Martynenko A. (2010). Heart Rate Variability for clinical practice. 2010. Kharkiv, Univer. Press, 131 p. (in Russ.) depositary: http://dspace.univer.kharkov.ua/handle/ 123456789/1462

3. Voss A, Schroeder R, Heitmann A, Peters A, Perz S. (2015) Short-Term Heart Rate VariabilityInfluence of Gender and Age in Healthy Subjects. PLoS ONE. 2015; 10 (3): e0118308

4. Shafler F., Ginsberg J.P. (2017). An Overview of Heart Rate variability Metrics and Norms // Frontiers in Public Health, v. 5, art. 258, p.1-17. https://doi.org/10.3389/fpubh.2017.00258

5. Dogan I. An Overview of Soft Computing. Procedia Computer Science. 12th International Conference on Application of Fuzzy Systems and Soft Computing, ICAFS 2016, Vienna, Austria. 102: 34-38 https://doi.org/10.1016/j.procs.2016.09.366

6. Yanase J., Triantaphyllou E. (2019). A Systematic Survey of Computer-Aided Diagnosis in Medicine: Past and Present Developments // Expert Systems with Applications.

138:112821. https://doi.org/10.1016/j.eswa.2019.112821

7. Martynenko A, Raimondi G, Budreiko N. Time Irreversibility and Complexity of Heart Rate Variability. Journal of V. N. Karazin` KhNU Series «Medicine». 2021; 41: 5-15. https://doi.org/10.26565/2313-66932021-41-01

8. Nunan D., Sandercock G., Brodie D. (2010). A quantitative systematic review of normal values for shortterm heart rate variability in healthy adults. Pacing Clin Electrophysiol. 2010; 33: 1407-1417.

9. Umetani K, Singer DH, McCraty R, Atkinson M. (1998). Twenty-four hour time domain heart rate variability and heart rate: relations to age and gender over nine decades. J Am Coll Cardiol. 1998

10. Nastanova z kardiologii (2009). Red. Kovalenko V.M., Kyiv, MOPIOH, 2009,1368 p. [in Ukrainian]

11. Goldberger, A.L. et al. (2000). Physiobank, physiotoolkit, and physionet: Components of a new research resource for complex physiologic signals. Circulation, 2000, 101, 215-220.

12. Moody GB, Mark RG. (1983). A new method for detecting atrial fibrillation using R-R intervals. Computers in Cardiology, 1983, 10: 227-230.

\section{НЕЧІТКА ЛОГІКА В ДИАГНОСТИЦІ ВАРІАБЕЛЬНОСТІ СЕРЦЕВОГО РИТМУ}

\section{Мартиненко О., Раймонді Д., Барсі Л., Будрейко М., Малярова Л.}

Вступ. Варіабельність серцевого ритму (ВСР) базується на вимірюванні (часу) інтервалів між Rпіками (RR-інтервалів) електрокардіограми (ЕКГ) 3 поданням їх у вигляді ритмограми і подальшого аналізу різними математичними, які класифікуються як методи (метрики) тимчасової області, частотної області і нелінійні. Різноманітність методів і підходів до аналізу ВСР обумовлено комплексністю і нелінійністю самого явища, а також великою різноманітністю фізіологічних реакцій організму, як в нормі, так і при патологічних станах. Тому, видається актуальним і важливим інкорпорування наявних на сьогоднішній день показників і норм ВСР в єдину методику, що дозволяє інтегрально оцінити кожну з метрик і результати ВСР в цілому.

Мета. У статті запропоновано алгоритм нечіткої логіки (FL) для включення в єдине уявлення кожної з метрик - тимчасової області (TD), частотної області (FD), нелінійних методів (NM) і ВCР в цілому.

Матеріали та методи. Ми визначаємо за допомогою FL ступінь приналежності до нормального стану як для кожного окремого показника $\mathrm{BCP}$ - TD, FD i NM, так і для ВCP пацієнта в цілому. Визначено функції приналежності до будь-якого індексу ВCP і правила дефуззіфікації для оцінок FL. Для реалізації запропонованого алгоритму в наукових публікаціях по ВСР знайдені задані параметри середніх значень показників ВСР (М) і їх стандартного відхилення $(\sigma)[1,3,7,8,9,10]$. Демонстрація 
роботи запропонованого алгоритму виконувалася на підставі 24-годинних записів ВСР з бази даних MIT-BIH [11] для пацієнтів з нормальним синусовим ритмом (NSR), серцевою недостатністю (CHF) i фібриляції передсердь (АF) [12].

Результати і висновки. Цілісний погляд на ВСР можливий тільки тоді, коли є технологія, подібна нечіткої логіки, що дозволяє об'єднати всі використовувані методи і підходи в інтегральну оцінку. Ми представили подібну FL технологію в цій статті і докладно розглянули особливості ії застосування та інтерпретації. 3 усіх розглянутих прикладів FL аналізу найгірший результат демонструє пацієнт 3 групи AF, а найкращий з групи NSR. Відмінність в FL оцінках у даних пацієнтів з груп NSR i CHF становить майже 4 рази, а у NSR і AF - майже 6 раз. Особливо важливим є імплементація подібної розробки в носяться медичних пристроях для швидкої і легкої інтерпретації численних параметрів, які вони вимірюють.

КЛЮЧОВІ СЛОВА: варіабельність серцевого ритму, нечітка логіка

\section{ИНФОРМАЦІЯ ПРО АВТОРІВ}

Мартиненко Олександр, д. фіз-мат. н., професор кафедри гігієни та соціальної медицини Харківського національного університету імені В. Н. Каразіна, пл. Свободи, 6, Харків, Україна, 61022, е-mail: Alexander.v.martynenko@karazin.ua, ORCID ID: https://orcid.org/0000-0002-0609-2220

ж. Раймонди, д. мед. н., проф., Римський університет Ла Сапієнца (Італія), Piazzale Aldo Moro, 5, Рим, Італія, 00185, e-mail: gianfrancoraimondi@uniroma1.it

Л. Барсі, доктор філософії, Римський університет Ла Сапієнца (Італія), Рiazzale Aldo Moro 5, Рим, Італія, 00185. Будрейко Микита, асистент кафедри гігієни та соціальної медицини Харківського національного університету імені В. Н. Каразіна, майдан Свободи, 6, Харків, Україна, 61022, e-mail: nbudreiko@protonmail.com

Малярова Людмила, асистент кафедри гігієни та соціальної медицини Харківського національного університету імені В. Н. Каразіна, майдан Свободи, 6, Харків, Україна, 61022, e-mail: 1.v.maliarova@karazin.ua

\section{НЕЧЕТКАЯ ЛОГИКА В ДИАГНОСТИКЕ ВАРИАБЕЛЬНОСТИ СЕРДЕЧНОГО РИТМА}

\section{Мартыненко А., Раймонди Д., Барси Л., Будрейко Н., Малярова Л.}

Введение. Вариабельность сердечного ритма (ВСР) базируется на измерении (времени) интервалов между R-пиками (RR-интервалов) электрокардиограммы (ЭКГ) с представлением их в виде ритмограммы и последующего анализа различными математическими, которые классифицируются как методы (метрики) временной области, частотной области и нелинейные. Разнообразие методов и подходов к анализу HRV обусловлено комплексностью и нелинейностью самого явления, а также большим разнообразием физиологических реакций организма, как в норме, так и при патологических состояниях. Поэтому, представляется актуальным и важным инкорпорирование имеющихся на сегодняшний день показателей и норм HRV в единую методику, позволяющую интегрально оценить каждую из метрик и результаты HRV в целом.

Цель. В статье предложен алгоритм нечеткой логики (FL) для включения в единое представление каждой из метрик - временной области (TD), частотной области (FD), нелинейных методов (NM) и ВСР в целом.

Материалы и методы. Мы определяем с помощью FL степень принадлежности к нормальному состоянию как для каждого отдельного показателя ВCP - TD, FD и NM, так и для ВCP пациента в целом. Определены функции принадлежности к любому индексу ВСР и правила дефуззификации для оценок FL. Для реализации предложенного алгоритма в научных публикациях по ВСР найдены заданные параметры средних значений показателей ВСР (М) и их стандартного отклонения $(\sigma)[1,3,7$, 8, 9, 10]. Демонстрация работы предложенного алгоритма выполнялась на основании 24-часовых записей ВСР из базы данных MIT-BIH [11] для пациентов с нормальным синусовым ритмом (NSR), сердечной недостаточностью (CHF) и фибрилляцией предсердей (AF) [12].

Результаты и выводы. Цельный взгляд на ВСР возможен только тогда, когда есть технология, подобная нечеткой логики, позволяющая объединить все используемые методы и подходы в интегральную оценку. Мы представили подобную FL технологию в настоящей статье и подробно рассмотрели особенности ее применения и интерпретации. Из всех рассмотренных примеров FL анализа худший результат демонстрирует пациент из группы AF, а наилучший из группы NSR. Отличие в FL оценках у данных пациентов из групп NSR и CHF составляет почти 4 раза, а у NSR и AF - почти 6 раз. Особенно важным представляется имплементация подобной разработки в носимых медицинских устройствах для быстрой и легкой интерпретации многочисленных параметров, которые они измеряют. 
КЛЮЧЕВЫЕ СЛОВА: вариабельность сердечного ритма, нечеткая логика

\section{ИНФОРМАЦИЯ ОБ АВТОРАХ}

Мартыненко Александр, д. физ-мат. н., профессор кафедры гигиены и социальной медицины Харьковского национального университета имени В. Н. Каразина, пл. Свободи, 6, Харьков, Украина, 61022, e-mail: Alexander.v.martynenko@karazin.ua, ORCID ID: https://orcid.org/0000-0002-0609-2220

Ж. Раймонди, д. мед. н., проф., Университет Рима «Сапиенза», 5, Piazzale Aldo Moro, Рим, Италия, 00185, e-mail: gianfrancoraimondi@uniroma1.it

Л. Барси, доктор философии, Университет Рима «Сапиенза», 5, Piazzale Aldo Moro, Рим, Италия, 00185.

Будрейко Никита, асистент кафедры гигиены и социальной медицины Харьковского национального университета имени В. Н. Каразина, пл. Свободи, 6, Харьков, Украина, 61022, e-mail: nbudreiko@ protonmail.com Малярова Людмила, ассистент кафедры гигиены и социальной медицины Харьковского национального университета имени В. Н. Каразина, пл. Свободи, 6, Харьков, Украина, 61022, e-mail: 1.v.maliarova@karazin.ua

Conflicts of interest: author has no conflict of interest to declare.

Конфлікт інтересів: відсутній.

Конфликт интересов: отсутствует.

Отримано: 05.04.2021 року Прийнято до друку: 17.05.2021 року 